\title{
Psychological Mechanism of Sinibularity of Assessing Learner's Listening Skills at Secondary Schools
}

\section{Психологічний механізм синібулярності в оцінюванні навичок аудіювання учнів у закладах середньої освіти}

\section{Ernest Ivashkevych}

Ph.D. in Psychology, Lecturer of the Department of Practice of English, Translator, Rivne State University of the Humanities, Rivne (Ukraine)

ORCID ID: https://orcid.org/0000-0001-7219-1086

Researcher ID: F-3865-2019

E-mail: ivashkevych.ee@gmail.com

\section{Ернест Івашкевич}

Кандидат психологічних наук, викладач кафедри практики англійської мови, перекладач, Рівненський державний гуманітарний університет, м. Рівне (Україна)

\section{Liudmyla Komarnitska}

Ph.D. in Philology, Lecturer of the Department of Social Work and Psychology, Podilskyi Special Educational and Rehabilitation Social-Economical College, Kamianets-Podilskyi (Ukraine)

ORCID ID: https://orcid.org/0000-0002-6742-8314

E-mail: kob-1974@ukr.net

\section{Людмила Комарніцька}

Кандидат філологічних наук, викладач кафедри соціальної роботи та психології, Подільський спеціальний навчально-реабілітаційний соціально-економічний коледж, м. Кам'янець-Подільський (Україна)

Address for correspondence, e-mail: kpnu_lab_ps@ukr.net Copyright: (C) Ivashkevych Ernest, Komarnitska Liudmyla

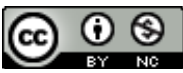

The article is licensed under CC BY-NC 4.0 International

(https://creativecommons.org/licenses/by-nc/4.0/)

(C) Ivashkevych Ernest, Komarnitska Liudmyla DOI (article): https://doi.org/10.32626/2227-6246.2020-50.53-74 
DOI: https://doi.org/10.32626/2227-6246.2020-50 2020. випуск 50

The contribution of the author: Ivashkevych E. - 50\%, Komarnitska L. $-50 \%$. Авторський внесок: Івашкевич Е. - 50\%, Комарніцька Л. - 50\%.

\section{ABSTRACT}

The aim of this research is to define different kinds of means for testing of the understanding of a listened audio-text, such as non-verbal means, verbal ones and reproductive means.

Methods of the research. There were used the following general scientific methods: the method of induction, deduction, analysis and synthesis, comparative and descriptive methods and explanatory ones.

The results of the research. There were proposed the tasks for pupils at the lessons of a foreign language, updated the psychological mechanism of the cumulative feature of recognition, which allowed us quickly, almost simultaneously formulate for each person a new task and to do its co-image and recognize it in a view of that new design. It was shown that recognition itself did not become a problem for the pupil, because that problem would be determined the significance of the task itself. However, such a possibility itself in terms of tremendous perception of some task is quite questionable, but, at the same time, the pupil performs this task. This psychological mechanism is the mechanism of sinibularity.

It was shown that sinibularity was a mechanism that actualized the similarity, compatibility of objects according to their individual components, details, features. It is the basis for the formation of associative chains and it is one of the factors that forms the concept. The sinibular associative chain is a mono-modal mental construction that will be created due to the identical features of different concepts of each object. The fixation of sinibular relations is based on the possibility of recognizing the object not only taking into account the pattern, but also understanding its individual details; irradiation of the significance of the object on its basic features and the peculiarities of their restructuring affects is based on some features, and the presence of form-semantic connections facilitate the connection of external features of the object with its internal qualities, properties and characteristics.

Conclusions. The psychological mechanism of sinibularity provides pupils with the solution of linguistic problems and tasks at the lessons of a foreign language by updating basic four components of the philological consciousness of the person: the identification of features (or characteristics) of a certain lexical C Ivashkevych Ernest, Komarnitska Liudmyla

DOI (article): https://doi.org/10.32626/2227-6246.2020-50.53-74 
or grammatical structure; the range of variations of their significance in the paradigm of this group of linguistic units (so-called objective concept); the level of acceptability of this variation; the differentiation of this concept, etc.

Key words: psychological mechanism of sinibularity, the cumulative feature of recognition, co-image, testing, associative chains, the concept, form-semantic connections, external features, internal qualities.

\section{Introduction}

First of all we have to underline that according to the requirements of the program at the end of the 2 nd form pupils have already distinguished between commonly used words, demonstrate their mutual understanding of the key words in the statement, understand and respond to questions that require «yes / no» or other simple answers, understand simple instructions, commands, perceive the main events of simple stories that the teacher tells with the help of visibility and other means. Also pupils can understand simple statements or the basic idea of authentic audio / video recording. Usually audio texts contain up to 4 sentences. For the next year pupils should understand the teacher's speech: short (up to 6 sentences) texts (announcements, dialogues, poems, songs) built on the learned material and sounded at normal pace. Pupils of the 4 th form already have to demonstrate the understanding of short texts, the volume of which is not more than 8 sentences, which may contain a small number of unknown words about the meaning of which they can guess.

The program of the 5 th form provides the formation of the pupils' ability to understand the information, both during direct communication with the speaker and indirectly (recording by the cassettes of a native speaker), presented at a normal rate of sound recording. Audio-texts can contain up to $1 \%$ of unknown words and individual grammatical phenomena understood from the context. The duration of the sound is up to 1 minute. At the end of the 6 th form texts proposed for listening may contain $2 \%$ of unknown words and individual grammati-

(C) Ivashkevych Ernest, Komarnitska Liudmyla DOI (article): https://doi.org/10.32626/2227-6246.2020-50.53-74 
DOI: https://doi.org/10.32626/2227-6246.2020-50 2020. випуск 50

cal phenomena understood from the context. The duration of the sound is up to 2 minutes.

There are no significant differences between the program requirements for listening for the $6^{\text {th }}$ and the $7^{\text {th }}$ forms. At the end of the seventh year of studying at schools pupils learning English at secondary schools should take the main points for texts' discussion, for example, they'd like to know what happens in this or that situation, provided that the speaker tells in some a way a clear normative language, which is typical for everyday conversations. Also the pupils have the opportunity to ask, to repeat some words or expressions; to understand the main content of texts, radio announcements, interviews about the events of the day or the topics of personal or professional interests envisaged by the program, to be able to select the necessary information from the heard material. The program also provides the best opportunities for the formation of the ability to use a linguistic and contextual guess based on a storyline or visibility. Audio texts can contain up to $2 \%$ of unknown words and individual grammatical phenomena understood from the context, and up to $1 \%$ of unknown words that do not interfere with the text's understanding in the whole. The duration of the sounded speech is up to 3 minutes.

By the end of the $9^{\text {th }}$ form pupils should understand the basic content of not very complex authentic texts of cognitive and ethnographic nature, highlight the main ideas, facts and arguments, differentiate between basic facts and secondary information in terms of its probability and persuasiveness, as well as to understand the content of not very complex authentic texts such as cognitive radio and television broadcasts, television and video films. Pupils should summarize the information they listened to, make on this basis their own conclusions, evaluate the information received in terms of its truthfulness. Pupils should also demonstrate the understanding of the most relevant information from authentic texts such as announcements, advertisements, reporting, they could evaluate selected (C) Ivashkevych Ernest, Komarnitska Liudmyla

DOI (article): https://doi.org/10.32626/2227-6246.2020-50.53-74 
facts about their usefulness, application of some possibilities and opportunities; the program provides the formation of the ability of schoolchildren to understand partners in communicative process (including the understanding of unfamiliar linguistic means), and, if it is necessary, using recipe and requesting, repeating or explaining. In such a way audio-texts will contain up to $3 \%$ of unknown words about the meanings you can guess from the context, and $1 \%$ of unfamiliar words that do not interfere with the comprehension of the text as a whole. The duration of the sound is up to 4 minutes.

By the end of the $10^{\text {th }}$ form the texts proposed by the teacher for listening would contain up to $3 \%$ of unknown words about the meaning of which pupils can guess from the context, and $2 \%$ of words that do not interfere with the comprehension of the text as a whole. The duration of sounds is up to 5 minutes. In the $11^{\text {th }}$ form, the program provides up to $4 \%$ of unknown words in audio-texts. The meaning of such words can be guessed from the context. Audio-texts can contain $2 \%$ of unknown words that do not interfere with the comprehension of the text as a whole. Text sound time is up to 6 minutes. In the last year of training pupils must understand audio that contains up to $5 \%$ of unknown words about the meaning of which can be guessed from the context, and $2 \%$ of unknown words that do not interfere with the comprehension of the text, which lasts for 6 minutes. When the teacher composes tasks for listening to, pupils should focus on software requirements. Audit comprehension testing can be done in verbal or non-verbal ways. The pupils' actions after listening to the message have to be related to the nature of the task that was put before their cognitive activity, which can provide different forms of transmission of comprehension of audio texts. These texts can be proposed for pupils in such forms: language (non-verbal actions of pupils) lifting hands, signal cards, drawings, doing the actions, production of schemes, selection of pictures accor-

(C) Ivashkevych Ernest, Komarnitska Liudmyla DOI (article): https://doi.org/10.32626/2227-6246.2020-50.53-74 
DOI: https://doi.org/10.32626/2227-6246.2020-50 2020. випуск 50

ding to the content, transferring, arrangement of plan items or blocks of text according to the logic of the context, making definitions of the main idea, completion of the statements, correction of incorrect statements, testing by the choice of the answer (alternative, one-element and multiple choice, cross-chain tests, classification tests, tests for the restoration of released sentence elements (cluster-tests) (Batel, 2020; de Bot, 1992; Mykhalchuk \& Ivashkevych, 2019). That's why the problem of psychological mechanism of assessing learner's listening skills at secondary schools is very actual nowadays.

According to these, the aim of this research is to define different kinds of means for testing of the understanding of listened audio-text, such as non-verbal means, verbal ones and reproductive means.

In order to achieve the aim stated in our research, we have to complete a set of the following objectives: to demonstrate the main ways of organizing training exercises for listening; to define the main conditions of authentic use of a foreign language in different educational situations; to propose techniques for forming audiences of adolescents; to determine the mechanism of sinibularity.

\section{Methods of the research}

Taking into account the impotence of the conventional methods of scientific research while dealing with the object of our article, the most substantial part of the methodological base for this research has been developed by us. The following general scientific methods were also used quite successfully: the method of induction, deduction, analysis and synthesis, comparative and descriptive methods and explanatory ones.

\section{Results and their discussion}

There are such kinds of means for testing of the understanding of listened audio-text. So, non-verbal means are: 1) doing the actions; 2) numeral testing; 3) testing with the (c) Ivashkevych Ernest, Komarnitska Liudmyla

DOI (article): https://doi.org/10.32626/2227-6246.2020-50.53-74 
DOI: https://doi.org/10.32626/2227-6246.2020-50 2020. випуСК 50

help of signal and accounted cards; 4) manufacturing of circuits, drawings; 5) selection of drawings (Хупавцева, 2020).

Verbal means are: receptive means: 1) confirmation or refutation of the teacher's statements; 2) choice of points of the text's plan; 3) tests with some choice of the answer. Reproductive means are: 1) answers to questions; 2) translation of the content into a foreign or a native language; 3 ) translation of words, phrases, sentences; 4) making a plan; 5) the formulation of questions to the text; 6 ) conversation based on the content of the text (Mykhalchuk \& Koval, 2019). Let's demonstrate the main ways of organizing training exercises for listening by the way of some examples.

Example 1. Listen to some words and determine whether they are the same or not. Place the "+» sign if they are the same, the «-» sign if they are different.

A phonogram:

1) house - mouse;

2) flat - flag;

3) room - broom;

4) bath - path;

5) wood - wool.

Pupil's card: $1 ; 2 ; 3 ; 4 ; 5$.

Means for testing are: pupils fill in the card.

Example 2. Listen to the statement and determine which picture belongs to another one by the best way. In the form of providing response under the approval number pupils have to write the letter indicating the corresponding figure.

Example 3. The teacher shows two drawings of objects (A and B) and names one of them. The pupils have to determine which of them is the statement. Along with the task number the pupil has to put the letter A or B.

Example 4. Look at the picture and listen to four phrases. Write the letter under which the phrase is corresponding to the image of the picture sounded.

A phonogram:

(C) Ivashkevych Ernest, Komarnitska Liudmyla DOI (article): https://doi.org/10.32626/2227-6246.2020-50.53-74 
DOI: https://doi.org/10.32626/2227-6246.2020-50

A. There's a statue of a lion.

B. The line is very straight.

C. The vine is near the window.

D. There's a lane near the building.

Means of testing: each pupil writes the corresponding letter.

Example 5. Listen to the phrase. Determine which of the sentences on your card corresponds to the content of this phrase. Place a sign next to this sentence «V».

A phonogram:

A. Bill has one brother and one sister, and so does Jane.

B. Bill has one brother and one sister named Jane.

C. Bill and Jane are brother and sister.

D. Bill's brother and sister like to be with Jane.

Means of testing: designation of the corresponding sentence (for example: V (A)).

Example 6. You are in one of the UK airports and you are waiting for the airplane to Ottawa. Listen to the announcement and write down the gallery number where it starts your plane to land on.

A phonogram: Passengers to Ottawa on Flight BD $335-$ this flight is now boarding at gate number 5. BD 335 to Ottawa boarding now at gate number 5 .

Means of testing: record a pupil in a gallery number of a notebook.

Example 7. You will hear a short conversation. You will hear the conversation twice. There is one question for each conversation. Put a tick under a right answer.

On tape: Peter: Hurry up! We'll be late.

Ann: What time does the train go?

Peter: At six fifteen. We must leave in ten minutes.

Ann: I'm nearly ready.

Pupil's card: What time does the train go?

1. (Below are images of clocks which show different time).

2. Means of testing: designation of corresponding drawing (for example: C).

(C) Ivashkevych Ernest, Komarnitska Liudmyla

DOI (article): https://doi.org/10.32626/2227-6246.2020-50.53-74 
3. Exercises for testing listened material may have the following character: to listen and to repeat the word, the phrase or several phrases, to combine phrases, to determine the difference between two phrases, to fill in the gaps in the graphic of the auditioned form, to select from the listed words those ones belonging to a certain topic.

Such exercises can be used during testing the listeners in forms 5-6 in order to interest children, promote the development of their imagination. The teacher should propose the following tasks: to listen to the beginning of the story and to come up with it, or to look at the picture, to listen to its description and to suggest its development.

To monitor the listener the teacher should submit the following tasks:

1) listen to the text, briefly convey its contents (4-5 sentences);

2) listen to the story and place the pictures that you have on the desk, according to the events in the story;

3) listen to two stories and tell how different they are;

4) listen to the story and say if there was such a sentence in it;

5) look at the picture and listen to the story. Tell us what differences you noticed;

6) listen to the teacher's story, then read the text that is close to you and emphasize the sentences that were not in the teacher's story;

7) listen to the text and select from several drawings one that corresponds to the content of the text;

8) determine which of two stories you listened to correspond to the contents of the picture;

9) listen to the story and select (think out) a headline for it. Explain why exactly you named the story in such a way.

The most important role is played by the instruction that contains a specific task for orienting pupils to purposeful and conscious understanding of information. Such a task organizes

(C) Ivashkevych Ernest, Komarnitska Liudmyla DOI (article): https://doi.org/10.32626/2227-6246.2020-50.53-74 
the pupil's thinking process, his / her attention and stimulates memorization in the process of listening.

Psychologists say that correct and accurate instruction can increase the perceived efficiency for $25 \%$. After listening to the pupils' audio text, the teacher has to check his / her understanding, which is a decisive step in the process of listening.

The main purpose of any educational system is the development of the pupil's person. Education is the basis and the mean of mental and in general - personal development of a man. However, learning has to be understood in relation to the subject "A foreign language», that is a process of communicatively oriented education, the concept of which is developed by foreign and Ukrainian methods of teaching.

Analyzing the features of communicative studying a foreign language, we understand the process of learning English as the method of organizing pupil- centered approach, which predetermines the development of a pupil as a person. The main methods of teaching are: the individualization of education, personal content of educational communication, providing moral-emotional and intellectual development of a pupil, personal autonomy of each schoolchild, the development of interpersonal relationships, the formation of the image of «himself / herself» as a carrier of a national culture (Vovk, Emishyants, Zelenko, Drobot \& Onufriieva, 2020). This means that the basis of communicatively oriented learning is the humanistic approach, which creates conditions for the active and free development of the pupil in the process of learning a foreign language.

The development of the individual should be understood not only as the extension of the horizons (the educational aspect), but also the development of intelligence (memory, thinking, attention, imagination) and intellectual operations (analysis, synthesis, classification, abstraction, concretization, choice, combination, decision-making). It is the development of value orientations, self-awareness, self-assessment of the interaction (C) Ivashkevych Ernest, Komarnitska Liudmyla

DOI (article): https://doi.org/10.32626/2227-6246.2020-50.53-74 
of the person within the social environment, that predominates the "socialization of the individual», which in general takes place in the context of the future of pupils' life.

In the educational process this aspect of personal development is emphasized by creating authentic conditions for foreign language communication, which involves not only the use of original educational materials but also their actual use. We think that it is absolutely necessary to use informative educational material, which contains knowledge about our reality and reflects the attitude towards them. Such material has to help the teacher to broaden the general outlook of the pupil, to obtain certain background knowledge for understanding the specific situations, to express his / her own thoughts according to a foreign language, to familiarize students with possible ways of speech behavior.

The authenticity of the use of foreign language teaching material can be achieved through its implementation in conditions that simulate situations of natural communication, for example, in situations close to our life, such as "a role play». Researchers of communicative-oriented learning also define such conditions of authentic use of a foreign language in different educational situations:

1. Use of interactive activities. Tasks are proposed for pairs of pupils or small groups, gradually realizing a task in the whole class. Three types of pupils' interaction are widely known: cooperation of participants in the development of a single idea; combining information known for various participants; transferring information from one pupil to another one.

2. Use of tasks with «information gap». Particularly valuable for personal development is the task of the "opinion gap" type, when pupils have different perspectives, points of view, and one needs to reach a common idea and a "reasoning gift» when different proofs need to be compared.

3. Use of problematic speech-minded tasks. Such tasks are based on the assumption, guessing, classification, finding simi-

(C) Ivashkevych Ernest, Komarnitska Liudmyla DOI (article): https://doi.org/10.32626/2227-6246.2020-50.53-74 
DOI: https://doi.org/10.32626/2227-6246.2020-50 2020. випуск 50

larities / differences, ranking, opening, interpreting, reasoning, judging, eliminating unnecessary information, sequencing of actions, causal reasoning, critical thinking.

4. Use of situations of spontaneous communication when the educational situation becomes a natural one.

These conditions are necessary for the development of the pupil's personality, they have to be ensured in the process of teaching and controlling such type of speech activity, as listening. Speech competence of upper-class pupils in listening includes the ability to understand the basic content of listened texts of different kinds, which contain a small number of unfamiliar words, on topics which are necessary in the educational program. Understanding the main content of the message is based on the ability of pupils to select the necessary information, to summarize and to compare it with their own experience, to highlight the main idea of the text, to evaluate its usefulness and probability, to predict the development of the plot, etc. The formation of these skills requires the combination of the activity of perception and comprehension of audio texts with the production of speech in oral or written form, which is natural for a two-way process of speech communication, the mechanisms of which are the reception and delivery of information.

Developing a technique for forming audiences of adolescents based on the text is necessary to adhere to three-phase activity with the audio text at the lesson. This activity includes three stages: a preparatory stage, the executive one and a final stage. It is worth noting that a final (post-text) phase includes a speech practice based on the content of the text and the production of statements which go beyond the content of the text (Максименко, Ткач, Литвинчук \& Онуфрієва, 2019).

The language practice actualizes the task of identifying, comprehending and reorganizing the content of the text. In such a way pupils' production is associated with the creation of their own statements to make semantic decisions which have (c) Ivashkevych Ernest, Komarnitska Liudmyla

DOI (article): https://doi.org/10.32626/2227-6246.2020-50.53-74 
to be spontaneous. Both textual and pre-text activity should provide the authentic use of text information in educational settings, preferably with the use of interactive modes. Therefore, from the standpoint of communicative learning audio text should stimulate the speech-thinking activity of senior pupils: its content should reveal certain aspects and provide the necessary information each person needs it to solve the problem. Post-text tasks should determine the research activities of pupils in which their readiness for speech-thinking activity is formed.

Such theoretical positions are implemented in the content of methodological tasks, which are given below. Pupils have to listen to the text «Recycling»; after that they are given the task to note which of the above statements correspond to the content of the text.

1. Americans do not usually wrap their purchases.

2. Packaging is always necessary and useful.

3. The average American discards 1,200 pounds of packaging each year.

4. «Composites» are packages containing several layers of materials and recyclable.

5. Packaging is always interesting.

6. Recycling uses the same materials again and again.

7. Much drinks come in aluminum cans.

8. Aluminum cannot be recycled.

9. The glass cannot be melted to make new bottles.

By completing this task, the pupils go to the next task (answer the questions).

1. When did recycling begin?

2. What does recycling mean?

3. What materials are easy to recycle?

4. Why are there different «composites» of this problem?

5. How long have cars been recycled?

6. How are metals, glass and paper recycled?

Then the teacher sets the task for pupils:

(C) Ivashkevych Ernest, Komarnitska Liudmyla DOI (article): https://doi.org/10.32626/2227-6246.2020-50.53-74 
DOI: https://doi.org/10.32626/2227-6246.2020-50 2020. випуск 50

Can you prove that recycling is a part of conservation? Do it.

Do the research. Visit a local supermarket and write the following:

1. Three products packaged in a cardboard: foil; glass; plastic; polyethylene.

2. Three products that are not packaged. They are...

3 . Three fruit or vegetables that come fresh can not be frozen. They are...

4. Products that come in aerosol cans are:...

5. Bags that the supermarket uses (paper / plastic).

Compare your answers with the responds of other colleague in small groups. Report your conclusions to the whole class.

Consequently, the tests for checking the development of listening skills make it possible not only to obtain the necessary information but also to promote the development of intellectual, creative and communicative skills.

In such a way listening is understood as a process of listening and understanding of verbal statements. The perception and understanding of speech directly depend on a number of factors that characterize the educational material and the mode of listening. According to all gradually complicated conditions of listening, being the main content of a special program. It is, for example:

1) the duration of the sound of the proposed texts;

2) the presence in the text of new strange words or some grammatical constructions;

3 ) the method of presentation of the text;

4) presence (or absence) of visual supports;

5) one-time or multiple presentation.

Testing of listened information should take at least some period of time and include into the process of cognitive activity as many students as it is possible. And so it is rather expedient to do in a writing form (Верещагина, 2000).

(C) Ivashkevych Ernest, Komarnitska Liudmyla

DOI (article): https://doi.org/10.32626/2227-6246.2020-50.53-74 
The most appropriate form of testing is providing tests for the whole form. For example, after listening to the text pupils can offer test tasks which the teacher needs:

1) to arrange (re-group) the statement in the correct order (pupils correspond the content with the information from the text they have read to the correct order);

2) to choose the correct answer to the questions from several proposed variants;

3) to determine the conformity of the statements of the content with the text having been listened, using the conditional designations «+» and «-», etc.;

4) to fill in the gaps in the text, in which the content of the story having been listened is presented in a concise form;

5) to continue the initiated sentences independently or to choose the correct variant from several proposed ones.

Samples of such tasks of texts have already been proposed by the each separate sample when it comes for checking reading skills of pupils. Also schoolchildren will offer tasks of the following type: to listen to the text and to fill in the letter for the answers to write the letters marked with the given pictures, in the sequence of sentences which correspond to the events having been described in the text. After listening to the text while performing the test task pupils are also invited to formulate the main idea of the text in 2-3 short sentences and to write them in the form of answers according to the task number. Sometimes, if it is possible, after listening to the text pupils can color the picture according to the content of listened information.

These tasks, proposed by us for pupils at the lessons of a foreign language, update the psychological mechanism of the cumulative feature of recognition, which allows us quickly, almost simultaneously formulate for each person a new task and to do its co-image and recognize it in a view of this new design (Mykhalchuk \& Bihunova, 2019). Therefore, recognition itself does not become a problem for the pupil, because this problem

(C) Ivashkevych Ernest, Komarnitska Liudmyla DOI (article): https://doi.org/10.32626/2227-6246.2020-50.53-74 
DOI: https://doi.org/10.32626/2227-6246.2020-50

2020. випуск 50

will be determined the significance of the task itself. However, such a possibility itself in terms of tremendous perception of some task is quite questionable, but, at the same time, the pupil performs this task. This psychological mechanism is the mechanism of sinibularity.

Sinibularity (from the Latin «sinibulis» - «similar») is a mechanism that actualizes the similarity, compatibility of objects according to their individual components, details, features. It is the basis for the formation of associative chains and it is one of the factors that forms the concept. The sinibular associative chain is a mono-modal mental construction that will be created due to the identical features of different concepts of each object. The fixation of sinibular relations is based on the possibility of recognizing the object not only taking into account the pattern, but also understanding its individual details; irradiation of the significance of the object on its basic features and the peculiarities of their restructuring affects is based on some features, and the presence of form-semantic connections facilitate the connection of external features of the object with its internal qualities, properties and characteristics.

Objects which belong to different groups of concepts might have not only differentiate features that allow their distribution, but also similar characteristics that provide some analogies. As a result, there may be more than one such symptom. Therefore, based on already known knowledge, well-known objects, etc., as well as using the psychological mechanism of the sinibular analogy, the subject can obtain a sufficiently large amount of information. The evaluative meaning of sinibularity is that if a completely new object cannot be evaluated as a whole, it can be characterized by individual details, the summurization of which creates a rough idea of the significance of the educational task as a whole.

DOI (article): https://doi.org/10.32626/2227-6246.2020-50.53-74 


\section{Conclusions}

Thus, sinibular qualities are based primarily on the fact that similar features of lexical and grammatical structures that the teacher offers to pupils should have similar characteristics, according to their conceptual affiliation. At the same time, the pupil creates certain sinibular concepts, that is a kind of mental constructions which are arisen as a result of establishing the associative connections between identical features of object's concepts of different levels. This level actualizes another one, no less important feature of lexical and grammatical units, which specify these features. Thus, according to the object, the pupil distinguishes in its structure certain details and features, which, however, have quite different specifics. Specifics of each concept will be those, which, as a result of close coordination of features, allow to assign this object to join to a certain conceptual group. The specificity of this or that feature determines the degree of generalization (or a level) of the concept. Therefore, there is a simultaneous actualization of individual-specific features, which, on the one hand, will characterize only this object and will allow its identification, and, on the other hand - to provide completely non-specific features that are inherent in almost any object, such as they do not play any role in solving this problem. Thus, the specificity of these features determines the level (a volume) of the sinibular concept that it forms.

Thus, the psychological mechanism of sinibularity provides pupils with the solution of linguistic problems and tasks at the lessons of a foreign language by updating basic four components of the philological consciousness of the person:

- the identification of features (or characteristics) of a certain lexical or grammatical structure;

- the range of variations of their significance in the paradigm of this group of linguistic units (so-called objective concept);

(C) Ivashkevych Ernest, Komarnitska Liudmyla DOI (article): https://doi.org/10.32626/2227-6246.2020-50.53-74 
DOI: https://doi.org/10.32626/2227-6246.2020-50

- the level of acceptability of this variation;

- the differentiation of this concept, etc.

The components of the philological consciousness of the person identified by us will be analyzed and detailed in our next publications.

\section{Literature}

Максименко С., Ткач Б., Литвинчук Л., Онуфрієва Л. Нейропсихолінгвістичне дослідження політичних гасел із зовнішньої реклами. Psycholinguistics. Психолінгвістика. Психолингвистика. 2019. Вип. 26 (1). С. 246-264. DOI 10.31470/2309-1797-2019-26-1-246264. URL : https://psycholing-journal.com/index.php/journal/article/view/715.

Хупавцева Н. O. Facilitation as a Personality-Centered Approach at the English Lessons at Secondary Schools. Проблели сучасної психологї: Зб. наук. праць Кал'янець-Подільського національного університету ілені Івана Огієнка, Інституту психології імені Г. С. Костюка НАПН України. Кам'янець-Подільський : ТОВ «Друкарня «Рута», 2020. Вип. 47. С. 206-230.

Batel, E. (2020). Context Effect on L2 Word Recognition: Visual Versus Auditory Modalities. Journal of Psycholinguist Research. Vol. 49. P. 223-245. URL : https://doi.org/10.1007/s10936-019-09683-6.

de Bot, K. (1992). A bilingual production model: Levelt's «speaking» model adapted. Applied Linguistics. Vol. 13. P. 1-24. URL : https://doi. org/10.1093/applin/13.1.1.

Mykhalchuk, N., \& Bihunova, S. (2019). The verbalization of the concept of «fear» in English and Ukrainian phraseological units. Cognitive Studies | Йtudes cognitives. Vol. 19. P. 11. Warsaw (Poland). URL : https://doi.org/10.11649/cs.2043.

Mykhalchuk, N., \& Ivashkevych, E. (2019). Psycholinguistic Characteristics of Secondary Predication in Determining the Construction of a Peculiar Picture of the World of a Reader. Psycholinguistics. Пcuxoлінгвістика. Психолингвистика. Вип. 25 (1). С. 215-231. DOI 10.31470/2309-1797-2019-25-1-215-231.

Mykhalchuk, N., \& Koval, I. (2019). Psychological content of effective means of teaching a foreign language in order to form the intercultural competence of learners of different age groups. Проблели сучасної психології: Зб. наук. праць Кам'янець-Подільського національного університету ілені Івана Огієнка, Інституту психологї̈ ілені Г. С. Костюка НАПН України. Кам'янець-Подільський : Аксіома. Вип. 46. С. 265-289.

(C) Ivashkevych Ernest, Komarnitska Liudmyla

DOI (article): https://doi.org/10.32626/2227-6246.2020-50.53-74 
Vovk, M., Emishyants, O., Zelenko, O., Drobot, O., \& Onufriieva, L. (2020). Psychological Features of Experiences of Frustration Situations in Youth Age. International Journal of Scientific \& Technology Research. Vol. 8, Issue 01, January. P. 920-924. URL : http:// www.ijstr.org/paper-references.php?ref=IJSTR-0120-28117.

\section{References}

Maksymenko, S., Tkach, B., Lytvynchuk, L., \& Onufriieva, L. (2019). Neiropsykholinhvistychne doslidzhennia politychnykh hasel iz zovnishnoi reklamy [A neuro-psycholinguistic study of political slogans in outdoor advertising]. Psycholinguistics. Psykholinhvistyka. Psikholingvistika - Psycholinguistics. Psycholinguistics. Psycholinguistics, 26 (1), 246-264. DOI 10.31470/2309-1797-2019-26-1-246-264. Retrieved from https://psycholing-journal.com/index.php/journal/article/ view/715 [in Ukrainian].

Khupavtseva, N. (2020). Facilitation as a Personality-Centered Approach at the English Lessons at Secondary Schools. Problemy suchasnoi psykholohii - Problems of Modern Psychology: Collection of research papers of Kamianets-Podilskyi National Ivan Ohiienko University, G. S. Kostiuk Institute of Psychology of the National Academy of Educational Sciences of Ukraine, 47, 206-230. Kamianets-Podilskyi : TOV «Drukarnia «Ruta».

Batel, E. (2020). Context Effect on L2 Word Recognition: Visual Versus Auditory Modalities. Journal of Psycholinguist Research, 49, 223245. Retrieved from https://doi.org/10.1007/s10936-019-09683-6.

de Bot, K. (1992). A bilingual production model: Levelt's «speaking» model adapted. Applied Linguistics, 13, 1-24. Retrieved from https:// doi.org/10.1093/applin/13.1.1.

Mykhalchuk, N., \& Bihunova, S. (2019). The verbalization of the concept of «fear» in English and Ukrainian phraseological units. Cognitive Studies | Йtudes cognitives, 19, 11. Warsaw (Poland). Retrieved from https://doi.org/10.11649/cs.2043.

Mykhalchuk, N., \& Ivashkevych, E. (2019). Psycholinguistic Characteristics of Secondary Predication in Determining the Construction of a Peculiar Picture of the World of a Reader. Psycholinguistics. Psykholinhvistyka. Psikholingvistika - Psycholinguistics. Psycholinguistics. Psycholinguistics, 25 (1), 215-231. DOI 10.31470/2309-17972019-25-1-215-231.

Mykhalchuk, N., \& Koval, I. (2019). Psychological content of effective means of teaching a foreign language in order to form the intercultural competence of learners of different age groups. Problemy su-

(C) Ivashkevych Ernest, Komarnitska Liudmyla DOI (article): https://doi.org/10.32626/2227-6246.2020-50.53-74 
DOI: https://doi.org/10.32626/2227-6246.2020-50 2020. ВипУСК 50

chasnoi psykholohii - Problems of Modern Psychology: Collection of research papers of Kamianets-Podilskyi National Ivan Ohiienko University, G. S. Kostiuk Institute of Psychology of the National Academy of Educational Sciences of Ukraine, 46, 265-289. Kamianets-Podilskyi : Aksioma.

Vovk, M., Emishyants, O., Zelenko, O., Drobot, O., \& Onufriieva, L. (2020). Psychological Features of Experiences of Frustration Situations in Youth Age. International Journal of Scientific \& Technology Research, 8 (1), 920-924. Retrieved from http://www.ijstr.org/ paper-references.php?ref=IJSTR-0120-28117.

Івашкевич Ернест, Комарніцька Людмила. Психологічний механізм синібулярності в оцінюванні навичок аудіювання учнів у закладах середньої освіти

\section{АНОТАЦІЯ}

Метою cmammi є визначення психологічних механізмів й окреслення засобів для перевірки розуміння прослуханого аудіотексту, таких як невербальні, словесні та репродуктивні засоби.

Методи дослідження. Використано такі загальнонаукові методи, як індукція, дедукція, аналіз і синтез, методи порівняння й опису, метод обгрунтування тощо.

Результати дослідження. Учням закладів середньої освіти було запропоновано завдання для їх виконання на уроках іноземної мови, які актуалізують психологічний механізм кумулятивної ознаки впізнавання, що дає змогу достатньо швидко, практично одночасно формулювати для кожного нового завдання свій ко-образ і здійснювати його впізнання вже з огляду на цю нову конструкцію. Тому саме по собі впізнання для учня не стає проблемою, адже проблемою буде визначення значущості самого завдання. Сама по собі така можливість за умов дискантного сприймання задачі є досить сумнівною, однак школяр виконує цю задачу. Психологічним механізмом при цьому є синібулярність.

Показано, що синібулярність (від лат. sinibulis - «подібний») - це механізм, який актуалізує подібність, сумісність об'єктів з огляду на їх окремі компоненти, деталі, ознаки. Вона є основою для утворення асоціативних ланцюжків і одним із чинників, що утворюють поняття. Синібулярний асоціативний ланцюжок являє собою мономодальну психічну конструкцію, що створюватиметься завдяки ідентичним ознакам різC Ivashkevych Ernest, Komarnitska Liudmyla

DOI (article): https://doi.org/10.32626/2227-6246.2020-50.53-74 
них об'єктних понять. Фіксація синібулярних відношень засновується на можливості впізнавання об'єкта не тільки з урахуванням патерну, але i з огляду на окремі деталі; іррадизація значущості об'єкта на його базові ознаки та значущість їх реструктурації впливають на значущість ранжування ознак, а наявність формо-змістових зв'язків фасилітує зв'язок зовнішніх ознак об'єкта з його внутрішніми якостями, властивостями та характеристиками.

Висновки. Визначено, що психологічний механізм синібулярності забезпечує розв'язання учнями лінгвістичних задач і завдань на уроках іноземної мови за допомогою актуалізації чотирьох компонентів філологічної свідомості особистості, до яких належать: ідентифрікація ознак (чи характеристик) певної лексичної або граматичної структури; діапазон варіації їх значущості в парадигмі певної групи лінгвістичних одиниць (так званого об'єктного поняття); рівень прийнятності даної варіації; диреренціація поняття.

Ключові слова: психологічний механізм синібулярності, особливість розпізнавання, ко-імідж, тестування, асоціативні ланцюги, концепт, формосемантичні зв'язки, екстернальні характеристики, інтернальні якості.

Ивашкевич Эрнест, Комарницкая Людмила. Психологический механизм синибулярности в оценке навыков аудирования учащихся в заведениях среднего образования

\section{АННОТАЦИЯ}

Целью статьи является определение психологических механизмов и средств для проверки понимания прослушанного аудиотекста, таких как невербальные, словесные и репродуктивные средства.

Методы исследования. Использованы такие основные научные методы, как индукция, дедукция, анализ и синтез, методы сравнения и описания, метод обоснования.

Результаты исследования. Учащимся заведений среднего образования были предложены задания, которые они должны были выполнить на уроках иностранного языка. Данные задания в большой степени актуализируют психологический механизм синибулярности, который, в свою очередь, позволяет достаточно быстро, практически одновременно формулировать для каждого нового задания свой ко-образ и осущест-

(C) Ivashkevych Ernest, Komarnitska Liudmyla DOI (article): https://doi.org/10.32626/2227-6246.2020-50.53-74 
влять его опознание уже с учетом этой новой конструкции. Поэтому само по себе опознание для ученика не становится проблемой, ведь проблемой будет определение значимости самой задачи. Сама по себе такая возможность в условиях дискантного восприятия задачи является весьма сомнительной, но, вместе с тем, школьник выполняет эту задачу. Психологическим механизмом при этом является синибулярность.

Показано, что синибулярность - это механизм, который актуализирует сходство, совместимость объектов с учетом их отдельных компонентов, деталей, признаков. Данный механизм является основой для образования ассоциативных иепочек и есть одним из факторов, образующих определенные понятия. Синибулярная ассоциативная цепочка представляет собой мономодальную психическую конструкцию, которая создается благодаря идентичным признакам различных объектных понятий. Фиксация синибулярных отношений основывается на возможности узнавания объекта не только с учетом паттерна, но и отдельных деталей; иррадизация значимости объекта с учетом его базовых признаков и значимость их реструктурации влияют на процедуру ранжирования признаков, а наличие формо-содержательных связей фасилиmирует способность личности к созданию связей внешних признаков объекта с его внутренними качествами, свойствами и характеристиками.

Выводы. Определено, что психологический механизм синибулярности обеспечивает решение учениками лингвистических задач и заданий на уроках иностранного языка с помощью актуализации четырех компонентов филологического сознания личности, таких как: идентификация признаков (или характеристик) определенной лексической или грамматической структуры; диапазон вариации их значимости в парадигме данной группы лингвистических единии (так называемого объектного понятия); уровень приемлемости данной вариации; дифференциация понятия.

Ключевые слова: психологический механизм синибулярности, особенность распознавания, ко-имидж, тестирование, ассоциативные цепи, концепт, формосемантические связи, экстернальные характеристики, интернальные качества.

Original manuscript received July 16, 2020

Revised manuscript accepted August 17, 2020 (C) Ivashkevych Ernest, Komarnitska Liudmyla

DOI (article): https://doi.org/10.32626/2227-6246.2020-50.53-74 